\title{
The emerging TDP-43 proteinopathy
}

\author{
George P. Paraskevas', Mara Bourbouli ${ }^{12}$, loannis Zaganas ${ }^{2}$, Elisabeth Kapaki ${ }^{1}$ \\ ${ }^{1}$ Cognitive and Movement Disorders Clinic and Neurochemistry Unit, 1st Department of Neurology, School of Medicine, National \\ and Kapodistrian University of Athens, Athens 11528, Greece. \\ ${ }^{2}$ Neurology Laboratory of the Department of Neurology, School of Medicine, University of Crete, Crete 71003, Greece.
}

Correspondence to: Dr. George P. Paraskevas, Cognitive and Movement Disorders Clinic and Neurochemistry Unit, 1st Department of Neurology, School of Medicine, National and Kapodistrian University of Athens, 72 Vas. Sofias Ave, Athens 11528, Greece. E-mail: geoprskvs44@gmail.com

\begin{abstract}
How to cite this article: Paraskervas GP, Bourbouli M, Zaganas I, Kapaki E. The emerging TDP-43 proteinopathy. Neuroimmunol Neuroinflammation 2018;5:17. http://dx.doi.org/10.20517/2347-8659.2018.18
\end{abstract}

Received: 3 Apr 2018 Accepted: 10 Apr 2018 Published: 10 May 2018

Science Editor: Athanassios P. Kyritsis Copy Editor: Guang-Zhe Zhu Production Editor: Cai-Hong Wang

Currently, neurodegenerative diseases are viewed as proteinopathies. In this context, a specific protein or peptide is involved in the pathogenesis of the disease by missfolding, polymerization, reduced degradation and final accumulation in the form of insoluble inclusions leading to neurodegeneration by various interacting mechanisms ${ }^{[1,2]}$. In Alzheimer's disease extracellular beta amyloid peptides and intracellular hyperphoshorylated tau proteins accumulate in the brain. In parkinsonian syndromes alpha synuclein $(\alpha-S y n)$ or $4 \mathrm{R}$ tau isoforms are found in various cytoplasmic inclusions.

In about $50 \%$ of patients with frontotemporal lobar degeneration (FTLD $)^{[3]}$ and about $90 \%$ of patients with amyotrophic lateral sclerosis (ALS) ${ }^{[4]}$, the responsible protein is the transactive response DNA binding protein-43 (TDP-43), forming ubiquitinated inclusions. The two clinical conditions may coexist in the same patient or the same family with TDP-43 being the major culprit in the ALS-FTLD spectrum ${ }^{[5]}$.

In an elegant study, Dong and Chen ${ }^{[6]}$ extensively reviewed the pathogenetic mechanisms of ubiquitinated TDP-43 in ALS, including abnormal aggregation with pathologic accumulation (oligo- and finally polymerization), redistribution from the nucleus to the cytoplasm, reduced clearance by autophagy and/or the ubiquitine-proteasome system, neurotoxicity and/or loss of function, complex interactions with other proteins and RNA affecting their function and prion-like behavior and spreading. Such an understanding of TDP-43 and its role in the mechanisms of the resulting proteinopathy, may prove to be important in two aspects, diagnosis and treatment.

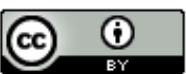

(C) The Author(s) 2018. Open Access This article is licensed under a Creative Commons Attribution 4.0 International License (https://creativecommons.org/licenses/by/4.0/), which permits unrestricted use, sharing, adaptation, distribution and reproduction in any medium or format, for any purpose, even commercially, as long as you give appropriate credit to the original author(s) and the source, provide a link to the Creative Commons license, and indicate if changes were made.

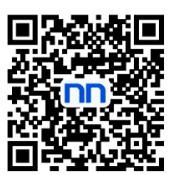




\section{DIAGNOSIS}

The various peptides and proteins involved in neurodegenerative diseases are secreted/released in the extracellular space and finally in the cerebrospinal fluid (CSF) by various mechanisms and some of them can be measured. Tau protein, either total or phosphorylated (phospho-tau) and beta amyloid peptide with 42 or 40 amino acids $\left(A \beta_{42}, A \beta_{40}\right)$ can be reliably measured in the CSF, and currently, are recognized as helpful in the diagnosis of Alzheimer's disease (inclusion) ${ }^{[7]}$ or its discrimination from other types of dementia, including the FTLDs (exclusion of $\mathrm{AD})^{[8,9]}$. Thus, the CSF biochemical profile of $\mathrm{AD}$ is well recognized (increased tau and phospho-tau, decreased $A \beta_{42}$ ). In synucleinopathies, $\alpha$-Syn is an emerging biomarker for Parkinson's disease, Dementia with Lewy Bodies and Multiple System Atrophy. A lot of studies have been conducted, while others are on their way towards better characterization of $\alpha$-Syn isoforms, antibodies used to recognize different epitopes and elimination of confounding factors interfering with preanalytical and analytical aspects, all with the purpose of establishing $\alpha$-Syn as a reliable biomarker in these disorders ${ }^{[10]}$.

On the other hand, the biochemical profile of TDP-43 proteinopathies has only recently begun to be explored and data are scarce and conflicting. Recently, however, CSF TDP-43 (either alone or in combination with other markers such as tau) has emerged as a candidate biomarker of ALS and FTLD and its levels are increased in both conditions ${ }^{[1,12]}$. Extensive investigation in order to determine and optimize its diagnostic potential is currently under way. Given the heterogeneity of proteinopathies, especially in FTLD (TDP-43 proteinopathies vs. tauopathies and others) and even within the TDP-43 proteinopathy in both ALS and FTLD (types A, B, $\mathrm{C}$ and $\mathrm{D}$ ), correcting CSF diagnosis may, additionally, prove helpful in the correct classification of patients in clinical trials ${ }^{[13]}$.

\section{TREATMENT}

Current treatments approved for ALS have modest effects and for FTLD are only symptomatic. The lack of success of pharmacological trials in such patient populations may be due to clinical trials being performed either too late in the course of the disease, with too short duration, inclusion of heterogeneous groups of patients, or insufficient knowledge about the specific clinical features and/or pathogenesis. The various steps in TDP-43 distribution, cytoplasmic accumulation, phosphorylation, ubiquitination, aggregation, autophagy, degradation, exosome secretion and toxicity may all be hypothetical targets of therapeutic interventions ${ }^{[13]}$ and some of them are currently tested in vitro and in animal models, including improved degradation, reduced neurotoxicity and antibodies against TDP- $43^{[6]}$.

In conclusion, mechanisms of TDP-43 abnormal accumulation and toxicity, extensively reviewed by Dong and $\mathrm{Chen}^{[6]}$ in addition to measurement of CSF TDP-43 levels as a diagnostic tool, are currently hot topics relevant to the majority of ALS and roughly half of FTLD patients.

\section{DECLARATIONS}

\section{Authors' contributions}

Concept and definition of intellectual content: Paraskervas GP, Bourbouli M, Zaganas I, Kapaki E Literature search: Paraskervas GP, Bourbouli M

Manuscript preparation: Paraskervas GP, Bourbouli M, Kapaki E

Manuscript editing and manuscript review: Paraskervas GP, Bourbouli M, Zaganas I, Kapaki E

\section{Financial support and sponsorship}

None.

\section{Conflicts of interest}

There are no conflicts of interest. 


\section{Patient consent}

Not applicable.

\section{Ethics approval}

Not applicable.

\section{Copyright}

(c) The Author(s) 2018.

\section{REFERENCES}

1. Fontana F, Siva K, Denti MA. A network of RNA and protein interactions in Fronto Temporal Dementia. Front Mol Neurosci $2015 ; 8: 9$.

2. Deng H, Wang P, Jankovic J. The genetics of Parkinson disease. Ageing Res Rev 2018;42:72-85.

3. Mackenzie IR, Neumann M. Molecular neuropathology of frontotemporal dementia: insights into disease mechanisms from postmortem studies. J Neurochem 2016;1:54-70.

4. Mackenzie IR, Bigio EH, Ince PG, Geser F, Neumann M, Cairns NJ, Kwong LK, Forman MS, Ravits J, Stewart H, Eisen A, McClusky L, Kretzschmar HA, Monoranu CM, Highley JR, Kirby J, Siddique T, Shaw PJ, Lee VM, Trojanowski JQ. Pathological TDP-43 distinguishes sporadic amyotrophic lateral sclerosis from amyotrophic lateral sclerosis with SOD1 mutations. Ann Neurol 2007;61:427-34.

5. Ling SC, Polymenidou M, Cleveland DW. Converging mechanisms in ALS and FTD: disrupted RNA and protein homeostasis. Neuron 2013;79:416-38.

6. Dong Y, Chen Y. The role of ubiquitinated TDP-43 in amyotrophic lateral sclerosis. Neuroimmunol Neuroinflammation 2018;5:5.

7. McKhann GM, Knopman DS, Chertkow H, Hyman BT, Jack CR, Kawas CH, Klunk WE, Koroshetz WJ, Manly JJ, Mayeux R, Mohs RC, Morris JC, Rossor MN, Scheltens P, Carrillo MC, Thies B, Weintraub S, Phelps CH. The diagnosis of dementia due to Alzheimer's disease: recommendations from the National Institute on Aging-Alzheimer's association workgroups on diagnostic guidelines for Alzheimer's disease. Alzheimers Dement 2011;7:263-9.

8. Kapaki E, Paraskevas GP, Papageorgiou SG, Bonakis A, Kalfakis N, Zalonis I, Vassilopoulos D. Diagnostic value of CSF biomarker profile in frontotemporal lobar degeneration. Alzheimer Dis Assoc Disord 2008;22:47-53.

9. Paraskevas GP, Kaselimis D, Kourtidou E, Constantinides V, Bougea A, Potagas C, Evdokimidis I, Kapaki E. Cerebrospinal fluid biomarkers as a diagnostic tool of the underlying pathology of primary progressive aphasia. J Alzheimers Dis 2017;55:1453-61.

10. Simonsen AH, Kuiperij B, El-Agnaf OM, Engelborghs S, Herukka SK, Parnetti L, Rektorova I, Vanmechelen E, Kapaki E, Verbeek M, Mollenhauer B. The utility of $\alpha$-synuclein as biofluid marker in neurodegenerative diseases: a systematic review of the literature. Biomark Med 2016;10:19-34.

11. Junttila A, Kuvaja M, Hartikainen P, Siloaho M, Helisalmi S, Moilanen V, Kiviharju A, Jansson L, Tienari PJ, Remes AM, Herukka SK. Cerebrospinal fluid TDP-43 in frontotemporal lobar degeneration and amyotrophic lateral sclerosis patients with and without the C9ORF72 hexanucleotide expansion. Dement Geriatr Cogn Dis Extra 2016;6:142-9.

12. Bourbouli M, Rentzos M, Bougea A, Zouvelou V, Constantinides VC, Zaganas I, Evdokimides I, Kapaki E, Paraskevas GP. Cerebrospinal fluid TAR DNA-binding protein 43 combined with tau proteins as a candidate biomarker for amyotrophic lateral sclerosis and frontotemporal dementia spectrum disorders. Dement Geriatr Cogn Disord 2017;44:144-52.

13. D' Alton S, Lewis J. Therapeutic and diagnostic challenges for frontotemporal dementia. Front Aging Neurosci 2014;6:204. 